\title{
Proximity to Liquor Stores and Adolescent Alcohol Intake: A Prospective
}

\section{Study}

Georgina S.A. Trapp, $\mathrm{PhD},{ }^{1,2,3}$ Matthew Knuiman, $\mathrm{PhD},{ }^{3}$ Paula Hooper, $\mathrm{PhD},{ }^{2}$ Sarah Foster, $\mathrm{PhD}^{4}$

From the ${ }^{1}$ Telethon Kids Institute, University of Western Australia, West Perth, Western Australia; ${ }^{2}$ Centre for the Built Environment and Health, University of Western Australia, Crawley, Perth, Western Australia; ${ }^{3}$ School of Global and Population Health, University of Western Australia, Crawley, Perth, Western Australia; and ${ }^{4}$ Royal Melbourne Institute of Technology University, Melbourne, Victoria, Australia

Address correspondence to: Georgina S.A. Trapp, PhD, Telethon Kids Institute, University of Western Australia, PO Box 855, West Perth, Western Australia, 6872. E-mail: gina.trapp@telethonkids.org.au. 
Introduction: Cross-sectional studies have reported associations between liquor store availability and alcohol use among adolescents, but few prospective studies have confirmed this association. The aim of this study was to examine whether proximity to liquor stores at age 14 years was associated with alcohol intake at ages 14, 17, and 20 years.

Methods: Participants of the Western Australian Pregnancy Cohort (Raine) Study ( $n=999)$ self-reported alcohol intake at age 14 years (early adolescence, 2003-2005), age 17 years (middle adolescence, 2006-2008), and age 20 years (late adolescence, 2009-2011). A GIS measured proximity to the closest liquor store from participants' home and school addresses at age 14 years. Regression analyses in 2017 assessed the relationship between distance to the closest liquor store around home, school, or both $(\leq 800 \mathrm{~m}$ vs $>800 \mathrm{~m})$ and alcohol intake. Results: In cross-sectional analyses (age 14 years), having a liquor store within $800 \mathrm{~m}$ of school was associated with ever having part of an alcoholic drink $(\mathrm{OR}=2.34, p=0.003)$. Also, having a liquor store within $800 \mathrm{~m}$ of home or school was associated with ever having part of an alcoholic drink $(\mathrm{OR}=1.49, p=0.029)$ and ever having engaged in heavy drinking $(\mathrm{OR}=1.79, p=0.023)$. In prospective analyses, liquor store proximity at age 14 years was a significant predictor of alcohol intake at age 17 years $(\mathrm{OR}=2.34, p=0.032)$ but not at age 20 years.

Conclusions: Liquor store availability in early adolescence may be a risk factor for alcohol intake in early and middle, but not late, adolescence. Improved understanding of the longerterm impacts of liquor store exposure on sensitive populations could help inform future licensing regulations. 


\section{INTRODUCTION}

Underage drinking is a major public health issue for many countries. ${ }^{1}$ In the U.S., United Kingdom, and Australia, around 20\%-30\% of secondary school students regularly consume alcohol and drinking to get wasted is perceived as integral to social life. ${ }^{2-7}$ Numerous negative health and social consequences are associated with underage drinking, including drug use, aggression and violence, unprotected sex, trouble in school or with the police, and increased risk of injuries and suicide. ${ }^{8-10}$ Moreover, the age at which young people start regular drinking is predictive of adult drinking and alcohol-related problems later in life. ${ }^{11}$ Accumulating evidence from neurologic research about the impact of adolescent drinking on impaired brain development ${ }^{12}$ further adds to the compelling need to identify influencing factors amenable to intervention.

Understanding how liquor store availability impacts underage drinking is an important research avenue as governments can regulate the location and density of liquor stores. International research shows adults living in neighborhoods with greater availability of liquor stores have higher alcohol intakes. ${ }^{13-16}$ Plausibly, the impact of widespread alcohol availability on adolescents may be more pronounced, given their receptivity to alcohol normalization, and the importance of proximate access for an age group with limited mobility. Indeed emerging evidence suggests liquor store availability impacts adolescent drinking. ${ }^{17}$ However, most studies are cross-sectional, few measure individual-level liquor store exposure around the home and school or measure an aspect of availability other than density. Therefore, this study aims to examine liquor store proximity around home and school at age 14 years and its association with alcohol intake at ages 14, 17, and 20 years.

\section{METHODS}




\section{Study Sample}

Participants were from the Western Australian Pregnancy Cohort (Raine) Study (88\%

Caucasian), ${ }^{18}$ resided in Perth and self-reported alcohol intake in early adolescence (age 14 years, 2003-2005, n=999), middle adolescence (age 17 years, 2006-2008, $n=648$ ) and late adolescence (age 20 years, 2009-2011, $n=696$ ). The following ethics committees provided approval: Princess Margaret Hospital, King Edward Memorial Hospital, the University of Western Australia.

\section{Measures}

Self-reported alcohol intake at ages 14 and 17 years used the binary items: Have you ever had even part of an alcoholic drink? (age 14 years only); Have you had an alcoholic drink in the past 12 months?; Have you been drunk anytime in the last 6 months?; Have you ever drunk 6 or more alcoholic drinks at one time or drunk so much alcohol that you threw up (vomited)? (heavy drinking measure). Self-reported alcohol intake (grams of ethanol/day) at age 20 years was assessed by the Cancer Council of Victoria ${ }^{19}$ (note: selling or supplying alcohol to anyone aged $<18$ years on licensed premises is illegal in Western Australia). ${ }^{20}$

Participants' home and school addresses at age 14 years were geocoded using GIS. Liquor store locations were sourced from an electronic telephone directory database (2005, SENSIS) and mapped in GIS. Distance-to-closest liquor store along the road network from home and school $(\leq 800 \mathrm{~m}$ vs $>800 \mathrm{~m})$ and presence of a liquor store within $800 \mathrm{~m}$ of home or school (yes versus no) was calculated. Adolescents perceive $800 \mathrm{~m}$ an easy walking distance. ${ }^{21}$

\section{Statistical Analysis}

Cross-sectional analyses used logistic regression to examine associations between distanceto-closest liquor store and alcohol intake. Prospective analyses applied logistic and linear 
regression to examine associations between distance-to-closest liquor store at age 14 years and alcohol consumption at ages 17 and 20 years, with and without adjusting for alcohol intake at age 14 years. All analyses in SPSS, version 24 controlled for gender and family income.

\section{RESULTS}

Sample characteristics are presented in Table 1. Cross-sectional analyses at age 14 years (Table $2 ; n=999$ ) revealed a consistent positive association (all ORs $>1.0$ ) between distanceto-closest liquor store from home, school, or both and the four alcohol intake measures. Three of the 12 associations reached statistical significance: a liquor store within $800 \mathrm{~m}$ of school was associated with a 2.34-fold increase in the odds of ever having part of an alcoholic drink; and a liquor store within $800 \mathrm{~m}$ of home or school was associated with a $49 \%$ increase in the odds of ever having part of an alcoholic drink and a $79 \%$ increase in the odds of ever engaging in heavy drinking.

In prospective analyses, there was a consistent positive association (all ORs $>1.0$ ) between distance-to-closest liquor store from home, school, or both at age 14 years and the three measures of alcohol intake at age 17 years (Table $3 ; n=648$ ). However, only one association reached statistical significance; an outlet within $800 \mathrm{~m}$ of home was associated with a 2.34fold increase in the odds of having an alcoholic drink in the past 12 months. No prospective association was found between distance-to-closest liquor store from home or school (or both) at age 14 years and alcohol intake at age 20 years (Table $4 ; n=696$ ).

\section{DISCUSSION}


This study found cross-sectional evidence that liquor stores proximate to home or school in early adolescence were positively associated with alcohol consumption. It also found partial evidence suggesting living close to a liquor store in early adolescence constituted a risk factor for alcohol consumption in middle, but not late, adolescence.

Positive associations between alcohol availability and alcohol consumption have been reported in other cross-sectional studies of young people. ${ }^{17,22-24}$ The findings were also consistent with a recent longitudinal Australian study ${ }^{25}$ that found living in areas with higher baseline liquor store density was associated with increased alcohol consumption 1-year later. Together, the emerging evidence and these results suggest greater regulation of community liquor stores could potentially reduce the proportion of young people engaging in underage drinking, with subsequent population-level health and social benefits.

Adolescent drinking behavior may be susceptible to proximate liquor stores for several reasons. For a population with limited mobility, having a store nearby increases the convenience of obtaining alcohol, either by asking a family member/stranger/peer to buy alcohol for them or purchasing it themselves. ${ }^{26,27}$ It may also influence parental alcohol purchases, potentially increasing alcohol accessibility at home. Further, a liquor store nearby may increase a young person's perceived availability of alcohol ${ }^{22-24}$ and reinforce normalization of drinking in their formative years. ${ }^{28}$ Indeed, Australian and U.S. research has implicated the prominent alcohol advertising associated with liquor stores with adolescent drinking. ${ }^{29,30}$ The mechanisms behind the finding that liquor store proximity at age 14 years is a risk factor for alcohol consumption in middle, but not late, adolescence warrant further investigation. Conceivably, exposure to liquor stores in early adolescence contributes to a perceived normalization of alcohol use, which is carried into middle adolescence. However, 
once at the legal drinking age, peer and family factors and increased mobility may have stronger influences on consumption than early environmental factors.

\section{Limitations}

Study strengths include the prospective design, inclusion of objective individual-level alcohol exposure measures around home and school, and the population-based sample. Although this study was novel in its focus on proximity to liquor stores, other accessibility factors (e.g., opening hours), within-store factors (e.g., prices/promotions) and license types (e.g., on premise, clubs) should be considered in future studies. Available control variables also limited the current study including whether teens moved closer or further from a liquor store over the time period, and inability to examine whether participants obtained alcohol from their closest outlet to home or school. Exposure to and use of liquor stores in other places adolescents spend their time (i.e., within their total activity space) should be examined in future studies. Furthermore, alcohol consumption was self-reported and the ever had part of an alcoholic drink variable did not distinguish participants who had only one sip from those consuming one or more standard drinks.

\section{CONCLUSIONS}

The findings highlight liquor store availability in early adolescence may be a risk factor for alcohol intake in early and middle, but not late, adolescence. Improved understanding of the longer-term impacts of liquor store exposure on sensitive populations could help inform future licensing regulations. 


\section{ACKNOWLEDGMENTS}

We are grateful to the Raine Study participants and their families and would like to thank the Raine Study Team for cohort coordination and data collection and the National Health and Medical Research Council (NHMRC) for their long-term contribution to funding the study over the last 25 years. Mrs. Bridget Beasley is gratefully acknowledged for her assistance in the development of the GIS measures in this study. The core management of the Raine Study is funded by The University of Western Australia; Curtin University; The Telethon Kids Institute; Raine Medical Research Foundation; The University of Western Australia Faculty of Medicine, Dentistry and Health Sciences; Women's and Infant's Research Foundation; Edith Cowan University; Murdoch University; and the University of Notre Dame. We would also like to acknowledge the grants that funded the 14-year follow-up: NHMRC (Sly et al., ID963209; Stanley and colleagues, ID003209) and The Raine Foundation; the 17-year follow-up: NHMRC (Stanley et al., ID353514); and the 20-year follow-up: NHMRC (Adams and colleagues, ID1021105). The current study was funded by a Department of Health (Western Australia) Targeted Research Fund grant. The first author is supported by a NHMRC Early Career Research Fellowship (ID1073233), second author by an Australian Research Council Discovery Early Career Researcher Award (DE160100140), and third author by a NHRMC Centres of Research Excellence in Healthy Liveable Communities postdoctoral fellowship (ID1061404).

GT and SF conceptualized the study. GT performed the analyses that were guided by MK and had input from SF and PH. GT drafted the manuscript. All authors interpreted findings, reviewed and edited drafts of the manuscript, and approved the final version. 
No financial disclosures were reported by the authors of this paper. 


\section{REFERENCES}

1. WHO. Global status report on alcohol and health - 2014 edition. WHO; 2014.

2. Kann L, McManus T, Harris WA, et al. Youth Risk Behavior Surveillance - United States, 2015. MMWR Surveill Summ. 2016;65(SS-6):1-74.

3. Center for Behavioral Health Statistics and Quality. 2015 National Survey on Drug Use and Health: Detailed Tables. Published 2016.

4. Johnston LD, O’Malley PM, Miech RA, Bachman JG, Schulenberg JE. Monitoring the future national survey results on drug use, 1975-2015: 2015 Overview-Key findings on adolescent drug use. Ann Arbor, MI: Institute for Social Research, University of Michigan; 2016.

5. Australian Institute of Health and Welfare. National Drug Strategy Household Survey detailed report 2013. Drug statistics series no. 28. Cat. no. PHE 183. Canberra; 2014.

6. Agalioti-Sgompou V, Christie S, Fiorini $\mathrm{P}$, et al. Smoking, drinking and drug use among young people in England in 2014. United Kingdom: Health and Social Care Information Centre; 2015.

7. Chainey TA, Stephens C. 'Let's get wasted': A discourse analysis of teenagers' talk about binge drinking. J Health Psychol. 2016;21(5):628-639. https://doi.org/10.1177/1359105314532972.

8. U.S. DHHS. The Surgeon General's Call to Action to Prevent and Reduce Underage Drinking. Rockville, MD: U.S. DHHS; 2007.

9. Miller JW, Naimi TS, Brewer RD, Jones SE. Binge drinking and associated health risk behaviors among high school students. Pediatrics. 2007;119(1):76-85. https://doi.org/10.1542/peds.2006-1517.

10. National Institute on Alcohol Abuse and Alcoholism. Underage drinking. NIH; 2017. 
11. Center for Behavioral Health Statistics and Quality. 2015 National Survey on Drug Use and Health: Detailed Tables. Rockville, MD; 2016.

12. Bava S, Tapert SF. Adolescent brain development and the risk for alcohol and other drug problems. Neuropsychol Rev. 2010;20(4):398-413. https://doi.org/10.1007/s11065-010-9146-6.

13. Campbell C, Hahn R, Elder R, et al. Guide to community preventive services: the effectiveness of limiting alcohol outlet density as a means of reducing excessive alcohol consumption and alcohol-related harms. Am J Prev Med. 2009;37(6):556569. https://doi.org/10.1016/j.amepre.2009.09.028.

14. Popova S, Giesbrecht N, Bekmuradov D, Patra J. Hours and days of sale and density of alcohol outlets: impacts on alcohol consumption and damage: a systematic review. Alcohol Alcohol. 2009;44(5):500-516. https://doi.org/10.1093/alcalc/agp054.

15. Gmel G, Holmes J, Studer J. Are alcohol outlet densities strongly associated with alcohol- related outcomes? A critical review of recent evidence. Drug Alcohol Rev. 2016;35(1):40-54. https://doi.org/10.1111/dar.12304.

16. Foster S, Trapp GSA, Hooper P, Oddy WH, Wood L, Knuiman M. Liquor landscapes: Does access to alcohol outlets influence alcohol consumption in young adults? Health Place. 2017;45:17-23.

https://doi.org/10.1016/j.healthplace.2017.02.008.

17. Bryden A, Roberts B, McKee M, Petticrew M. A systematic review of the influence on alcohol use of community level availability and marketing of alcohol. Health Place. 2012;18(2):349-357. https://doi.org/10.1016/j.healthplace.2011.11.003.

18. Newnham JP, Evans SF, Michael CA, Stanley FJ, Landau LI. Effects of frequent ultrasound during pregnancy: a randomised controlled trial. Lancet. 1993;342(8876):887-891. https://doi.org/10.1016/0140-6736(93)91944-H. 
19. Hodge A, Patterson AJ, Brown WJ, Ireland P, Giles G. The Anti Cancer Council of Victoria Food Frequency Questionnaire: relative validity of nutrient intakes compared with weighed food records in young to middle-aged women in a study of iron supplementation. Aust N Z J Public Health. 2000;24(6):576-583. https://doi.org/10.1111/j.1467-842X.2000.tb00520.x.

20. Western Australian Police Force. Alcohol and the law. Western Australia; 2014.

21. Colabianchi N, Dowda M, Pfeiffer KA, Porter DE, Almeida MJC, Pate RR. Towards an understanding of salient neighborhood boundaries: adolescent reports of an easy walking distance and convenient driving distance. Int J Behav Nutr Phys Act. 2007;4(1):66. https://doi.org/10.1186/1479-5868-4-66.

22. Rowland B, Toumbourou JW, Satyen L, et al. Associations between alcohol outlet densities and adolescent alcohol consumption: A study in Australian students. Addict Behav. 2014;39(1):282-288. https://doi.org/10.1016/j.addbeh.2013.10.001.

23. Stanley LR, Henry KL, Swaim RC. Physical, social, and perceived availabilities of alcohol and last month alcohol use in rural and small urban communities. $J$ Youth Adolesc. 2011;40(9):1203-1214. https://doi.org/10.1007/s10964-010-9556-Z.

24. Kuntsche E, Kuendig H, Gmel G. Alcohol outlet density, perceived availability and adolescent alcohol use: a multilevel structural equation model. J Epidemiol Community Health. 2008;62(9):811-816. https://doi.org/10.1136/jech.2007.065367.

25. Rowland B, Evans-Whipp T, Hemphill S, Leung R, Livingston M, Toumbourou J. The density of alcohol outlets and adolescent alcohol consumption: An Australian longitudinal analysis. Health Place. 2016;37:43-49.

https://doi.org/10.1016/j.healthplace.2015.11.004. 
26. Rowland B, Toumbourou JW, Livingston M. The association of alcohol outlet density with illegal underage adolescent purchasing of alcohol. J Adolesc Health. 2015;56(2):146-152. https://doi.org/10.1016/j.jadohealth.2014.08.005.

27. Chen M-J, Gruenewald PJ, Remer LG. Does alcohol outlet density affect youth access to alcohol? J Adolesc Health. 2009;44(6):582-589. https://doi.org/10.1016/j.jadohealth.2008.10.136.

28. Alcohol Concern Youth Policy Project. One on every corner - The relationship between off-license density and alcohol harms in young people. London: Alcohol Concern; 2011.

29. Pasch KE, Komro KA, Perry CL, Hearst MO, Farbakhsh K. Outdoor alcohol advertising near schools: what does it advertise and how is it related to intentions and use of alcohol among young adolescents? J Stud Alcohol Drugs. 2007;68(4):587-596. https://doi.org/10.15288/jsad.2007.68.587.

30. Jones SC, Magee CA. Exposure to alcohol advertising and alcohol consumption among Australian adolescents. Alcohol Alcohol. 2011;46(5):630-637. https://doi.org/10.1093/alcalc/agr080. 
Table 1. Characteristics of Sample

\begin{tabular}{|c|c|c|c|}
\hline Characteristic & $\begin{array}{c}\text { Early } \\
\text { adolescence } \\
(14 \text { years, } \\
\text { n=999) } \\
\mathbf{n}(\%)\end{array}$ & $\begin{array}{c}\text { Middle } \\
\text { adolescence } \\
(17 \text { years, } \\
\text { n=648) } \\
\text { n }(\%)\end{array}$ & $\begin{array}{c}\text { Late } \\
\text { adolescence } \\
(20 \text { years, } \\
\text { n=696) } \\
\text { n }(\%)\end{array}$ \\
\hline \multicolumn{4}{|l|}{ Gender } \\
\hline Female & $500(50.1)$ & $335(51.7)$ & $360(51.7)$ \\
\hline Male & $499(49.9)$ & $313(48.3)$ & $336(48.3)$ \\
\hline \multicolumn{4}{|l|}{ Family income at 14 years } \\
\hline$<\$ 35,000$ & $222(23.4)$ & $122(19.7)$ & $123(18.5)$ \\
\hline$\$ 35,001-\$ 50,000$ & $148(15.6)$ & $90(14.5)$ & $97(14.6)$ \\
\hline$\$ 50,001-\$ 78,000$ & $268(28.2)$ & $182(29.4)$ & $199(30.0)$ \\
\hline$\$ 78,001-\$ 104,000$ & $145(15.3)$ & $103(16.6)$ & $116(17.5)$ \\
\hline$\geq \$ 104,001$ & $166(17.5)$ & $123(19.8)$ & $129(19.4)$ \\
\hline \multicolumn{4}{|c|}{ Alcohol consumption } \\
\hline \multicolumn{4}{|c|}{ Ever had part of an alcoholic drink } \\
\hline Yes & $800(80.1)$ & $616(95.2)$ & \\
\hline No & $199(19.9)$ & $31(4.8)$ & \\
\hline \multicolumn{4}{|c|}{ Had an alcoholic drink in the past } \\
\hline Yes & $595(59.6)$ & $586(90.4)$ & \\
\hline No & $389(38.9)$ & $62(9.6)$ & \\
\hline \multicolumn{4}{|c|}{ Been drunk in the last 6 months } \\
\hline Yes & $113(11.5)$ & $441(68.7)$ & \\
\hline No & $868(88.5)$ & $201(31.3)$ & \\
\hline \multicolumn{4}{|c|}{ Ever engaged in heavy drinking } \\
\hline Yes & $76(7.7)$ & $395(61.5)$ & \\
\hline No & $908(92.3)$ & $247(38.5)$ & \\
\hline $\begin{array}{l}\text { Alcohol consumption (g } \\
\text { ethanol/day), mean (SD) }\end{array}$ & & & $\begin{array}{c}696(17.6 \\
18.6)\end{array}$ \\
\hline \multicolumn{4}{|c|}{$\begin{array}{l}\text { Distance-to-closest liquor store at } 14 \\
\text { years }\end{array}$} \\
\hline \multicolumn{4}{|c|}{ From home } \\
\hline$\leq 800 \mathrm{~m}$ & $240(24.0)$ & & \\
\hline$>800 \mathrm{~m}$ & $759(76.0)$ & & \\
\hline \multicolumn{4}{|l|}{ From school } \\
\hline$\leq 800 \mathrm{~m}$ & $155(15.5)$ & & \\
\hline$>800 \mathrm{~m}$ & $844(84.5)$ & & \\
\hline \multicolumn{4}{|c|}{$\begin{array}{l}\text { Has an liquor store within } 800 \mathrm{~m} \\
\text { of home or school }\end{array}$} \\
\hline Yes & $346(34.6)$ & & \\
\hline No & $653(65.4)$ & & \\
\hline
\end{tabular}


Table 2. Association Between Liquor Store Proximity at 14 Years and Alcohol Consumption at 14 Years (Logistic Regression)

\begin{tabular}{|c|c|c|c|c|c|c|c|c|}
\hline \multirow[t]{2}{*}{$\begin{array}{l}\text { Distance-to-closest } \\
\text { liquor store }\end{array}$} & \multicolumn{2}{|c|}{$\begin{array}{l}\text { Ever had part of an } \\
\text { alcoholic drink }^{\text {a }}\end{array}$} & \multicolumn{2}{|c|}{$\begin{array}{l}\text { Had an alcoholic drink in } \\
\text { the past } 12 \text { months }\end{array}$} & \multicolumn{2}{|c|}{$\begin{array}{c}\text { Been drunk in the last } 6 \\
\text { months }^{\mathrm{a}}\end{array}$} & \multicolumn{2}{|c|}{$\begin{array}{c}\text { Ever engaged in heavy } \\
\text { drinking }^{\mathrm{a}}\end{array}$} \\
\hline & OR (95\% CI) & $\begin{array}{c}p- \\
\text { value }\end{array}$ & OR (95\% CI) & $\begin{array}{c}p- \\
\text { value }\end{array}$ & OR $(95 \%$ CI $)$ & $\begin{array}{c}p \text { - } \\
\text { value }\end{array}$ & OR (95\% CI) & $\begin{array}{c}p- \\
\text { value }\end{array}$ \\
\hline $\begin{array}{l}\leq 800 \mathrm{~m} \text { around home } \\
\text { (ref: }>800 \mathrm{~m} \text { ) }\end{array}$ & $1.26(0.85,1.87)$ & 0.250 & $1.14(0.83,1.56)$ & 0.421 & $1.20(0.75,1.90)$ & 0.450 & $1.59(0.92,2.74)$ & 0.095 \\
\hline $\begin{array}{l}\leq 800 \mathrm{~m} \text { around school } \\
\text { (ref: }>800 \mathrm{~m} \text { ) }\end{array}$ & $2.34(1.33,4.10)$ & 0.003 & $1.35(0.93,1.97)$ & 0.118 & $1.03(0.59,1.80)$ & 0.920 & $1.62(0.88,2.99)$ & 0.120 \\
\hline $\begin{array}{l}\text { Has a liquor store within } \\
800 \text { m of home or school } \\
\text { (ref: no) }\end{array}$ & $1.49(1.04,2.13)$ & 0.029 & $1.14(0.86,1.51)$ & 0.357 & $1.21(0.80,1.85)$ & 0.371 & $1.79(1.08,2.97)$ & 0.023 \\
\hline
\end{tabular}
(ref: no)

Note: Boldface indicates statistical significance $(p<0.05)$.

${ }^{a}$ Adjusted for gender and family income. 
Table 3. Association Between Liquor Store Proximity at 14 Years and Alcohol Consumption at 17 Years (Logistic Regression)

\begin{tabular}{|c|c|c|c|c|c|c|}
\hline \multirow[t]{2}{*}{$\begin{array}{l}\text { Distance-to-closest } \\
\text { liquor store }\end{array}$} & \multicolumn{2}{|c|}{$\begin{array}{l}\text { Had an alcoholic drink in the past } \\
12 \text { months }\end{array}$} & \multicolumn{2}{|c|}{ Been drunk in the last 6 months $\mathrm{s}^{\mathrm{a}}$} & \multicolumn{2}{|c|}{ Ever engaged in heavy drinking ${ }^{\mathrm{a}}$} \\
\hline & $\begin{array}{c}\text { Model 1 } \\
\text { OR }(95 \% \text { CI }) \\
\end{array}$ & $\begin{array}{c}\text { Model } 2 \\
\text { OR }(95 \% \mathrm{CI}) \\
\end{array}$ & $\begin{array}{c}\text { Model } 1 \\
\text { OR }(95 \% \text { CI }) \\
\end{array}$ & $\begin{array}{c}\text { Model } 2 \\
\text { OR }(95 \% \text { CI }) \\
\end{array}$ & $\begin{array}{c}\text { Model } 1 \\
\text { OR }(95 \% \text { CI }) \\
\end{array}$ & $\begin{array}{c}\text { Model } 2 \\
\text { OR }(95 \% \text { CI })\end{array}$ \\
\hline $\begin{array}{l}\leq 800 \mathrm{~m} \text { around home } \\
\text { (ref: }>800 \mathrm{~m} \text { ) }\end{array}$ & $2.34(1.08,5.06)^{*}$ & $2.42(1.05,5.60)^{*}$ & $1.42(0.94,2.13)$ & $1.41(0.92,2.15)$ & $1.24(0.84,1.82)$ & $1.22(0.82,1.82)$ \\
\hline $\begin{array}{l}\leq 800 \mathrm{~m} \text { around school } \\
\text { (ref: }>800 \mathrm{~m} \text { ) }\end{array}$ & $1.38(0.63,3.00)$ & $1.08(0.48,2.43)$ & $1.22(0.77,1.95)$ & $1.16(0.72,1.87)$ & $1.23(0.79,1.92)$ & $1.20(0.77,1.89)$ \\
\hline $\begin{array}{l}\text { Has an liquor store } \\
\text { within } 800 \text { m of home } \\
\text { or school (ref: no) }\end{array}$ & $1.70(0.93,3.10)$ & $1.61(0.85,3.05)$ & $1.29(0.90,1.85)$ & $1.23(0.85,1.78)$ & $1.33(0.94,1.89)$ & $1.31(0.92,1.87)$ \\
\hline
\end{tabular}

Model 1: Adjusted for gender and family income

Model 2: Adjusted for gender, family income and alcohol intake at $14 \mathrm{yrs}$ (same variable as at $17 \mathrm{yrs}$ )

Note: Boldface indicates statistical significance ${ }^{*} p<0.05$ 
Table 4. Association Between Liquor Store Proximity at 14 Years and Alcohol Consumption (Grams-Ethanol/Day) at 20 Years (Linear Regression)

\begin{tabular}{lcccc}
\hline $\begin{array}{l}\text { Distance-to-closest } \\
\text { liquor store }\end{array}$ & \multicolumn{2}{c}{ Model 1 } & \multicolumn{2}{c}{ Model 2 } \\
\cline { 2 - 5 } & B (95\% CI) & $\boldsymbol{p}$-value & B (95\% CI) & $\boldsymbol{p}$-value \\
\hline $\begin{array}{l}\leq 800 \mathrm{~m} \text { around home } \\
\text { (ref: }>800 \mathrm{~m})\end{array}$ & $2.06(-1.12,5.24)$ & 0.203 & $1.89(-1.31,5.09)$ & 0.246 \\
$\leq 800 \mathrm{~m}$ around school & $0.12(-3.66,3.99)$ & 0.950 & $-0.67(-4.43,3.09)$ & 0.729 \\
$\begin{array}{l}\text { (ref: }>800 \mathrm{~m}) \\
\text { Has an liquor store }\end{array}$ & $1.55(-1.32,4.42)$ & 0.290 & $1.20(-1.68,4.08)$ & 0.415 \\
$\begin{array}{l}\text { within } 800 \mathrm{~m} \text { of home or } \\
\text { school (ref: no) }\end{array}$ & & & & \\
\hline $\begin{array}{l}\text { Notes: Model 1: Adjusted for gender and family income. Model 2: Adjusted for alcohol } \\
\text { intake at 14 years (Had a drink in the past 12 months), gender, and family income. }\end{array}$ &
\end{tabular}

